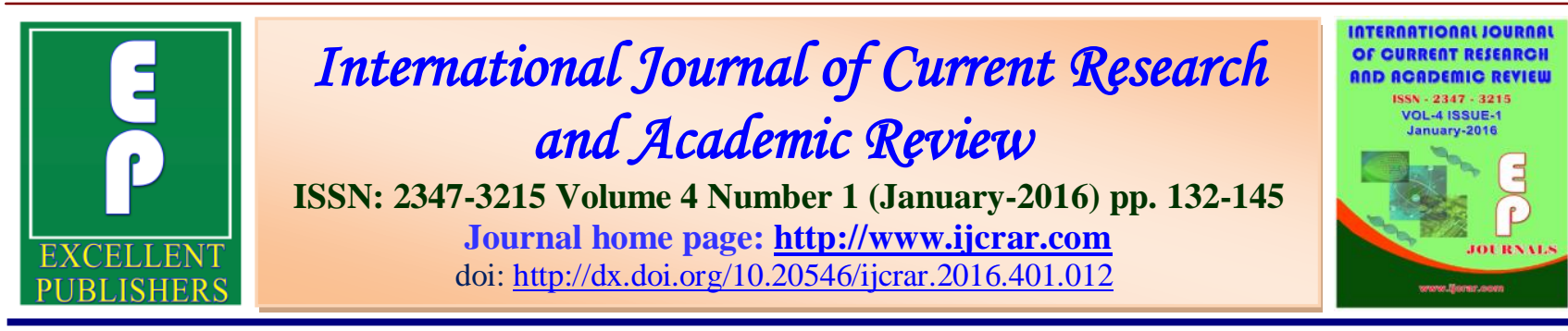

\title{
Approaches on Nano-based drug delivery for Alzheimer's Disease: Methods for Diagnosis, Pharmacology and Safety matter
}

\author{
Rakesh Kumar Singh* \\ Department of Chemistry, University of Allahabad, Allahabad- 211002, India \\ *Corresponding author
}

\begin{tabular}{|l|l|}
\hline \multirow{2}{*}{$\begin{array}{l}\text { KEYWORDS } \\
\text { Nanoparticles, }\end{array} \begin{array}{l}\text { Nanotechnology, } \\
\text { Polyphenols, } \\
\text { MRI }\end{array}$} & $\begin{array}{l}\text { The large number of people diagnosed with a neurodegenerative disorder i.e. } \\
\text { Alzheimer's disease (ADs), a increasing rapidly. AD is the most common } \\
\text { form of dementia worldwide, affecting more than more than } 35 \text { million } \\
\text { people. It is characterized by memory dysfunction, spatial and temporal } \\
\text { orientation, and loss of lexical access. Although clinical development of } \\
\text { drugs for the symptomatic and disease modifying treatment of AD. A large } \\
\text { number of drugs with different mode of targets and their mechanism were } \\
\text { investigated. The targeted nano based drug (eg. Nanoparticles: NPs) delivery } \\
\text { to the central nervous system (CNS), for diagnosis and treatment of AD, due } \\
\text { to limitations posed by the restrictive blood brain barrier (BBB). This review } \\
\text { literature provides a concise approach into the current and future applications } \\
\text { of nano based medicine for the treatment of ADs, besides reviewing and } \\
\text { discussing the literature on the drug delivery, their diagnosis and treatment } \\
\text { for safety point of view in Alzheimer's. }\end{array}$ \\
\hline
\end{tabular}

\section{Introduction}

The application of nano based medicine in neurological research areas are expected to have a major impact leading to the exploration of newer therapeutic modalities. Nanotechnological devices with the smallest functional organization on the nano-meter scale $(1-100 \mathrm{~nm})$ that are the able to interact with biological systems at molecular level, they may stimulate and interact with target tissues and cells. Nanotechnology offers ways to manipulate complex biological systems with greater selectivity and specificity than the conventional pharmacological approaches such as the blood brain barrier (BBB) in Alzheimer's disease $(\mathrm{AD})$.

Alzheimer's disease is a neurodegerative disorder (ND) are specific category of brain disease, common form of dementia among people elderly ages more than 65 years and encompasses a variety of conditions that 
familial or sporadic characterized by the persistent loss of neuronal activity. Due to the aging of the human population $\mathrm{AD}$ affects 24.3 million people worldwide and increases socio-economic, financial and medical burden. (Ferri et al., 2005). The National Institutes of Health (NIH) estimates that 4.5 million Americans are affected by $\mathrm{AD}$. In this continuation, the estimated annual cost of healthcare is over $\$$ 100 billion every year and in the coming time, estimate that by 2050, 13.2 million over age Americans are expected to have $\mathrm{AD}$.

$\mathrm{AD}$ is mainly characterized by three major pathophysiological characteristics; The dysregulation of the cholinergic systems, (Teipel et al., 2011; Parent et al., 2013). the senile plaque accumulation made of $\beta$ amyloid peptide aggregates and the apparition of neurofibrillary tangles resulting from the hyperphosphorylation of Tau protein (Augustinack et al., 2002). $\beta$ Amyloid peptides are derived from amyloid precursors that can undergo several cleavages by $\beta$-, $\gamma$ - and $\alpha$-secretase. In $\mathrm{AD}$, $\beta$-amyloid peptides accumulate and lead to toxic fibrillary aggregation also known as senile plaques (Sinha and Lieberburg, 1999). Those aggregates severely impair the viability of neurons by disrupting brain parts composed of unmyelinated neurons, dendrites and glial cells also known as neuropil (Murphy and LeVine, 2010). On the other hand internal cell dysregulations observed in AD patients cause a hyperphosphorylation of Tau, which severely impairs the axon integrity and the neurotransmitter transport (Sun et al., 2003). Moreover, there is increasing evidence showing that those three hallmarks are closely interconnected, which tend to indicate that upcoming therapeutic measures should act simultaneously on all of them (Busciglio et al., 1995; Ferreira et al., 1997; Zheng et al., 2002).
The current treatments for $\mathrm{AD}$ are mostly acetylcholine esterase inhibitors (Rivastigmine, Dopenezil, Galantamine) or NMDAR inhibitor (Memantine). Those inhibitors show only transient effects without stopping the progression of the disease and are mainly administered orally or transdermally (Hansen et al., 2008; Molino et al., 2013).

Drug delivery to the brain still remains a highly challenging for the treatment of AD. The development of new practical treatment modalities for the treatment of $\mathrm{AD}$ is currently a highly active research area among the scientific community.

Among these, nanotechnology-based strategies have gained tremendous importance as some of them are capable of overcoming the limitations inherent to $\mathrm{BBB}$ passage. These include various types of lipidic, polymeric, inorganic, and other types of NPs for controlled drug delivery to various CNS conditions (Silva, 2010).

Some strategies have been directed towards encapsulation of several types of biologically active molecules into NPs for their (targeted) delivery to the brain. Others some have focused on the use of nanovectors to overcome the toxicity of amyloid clusters by promoting their clearance or by altering their aggregation kinetics in the brain and in the blood, peripheral treatment with molecules that have high affinity for $A \beta$ can reduce the level of $A \beta$ in the brain through the sink effect. Engineered NPs exhibiting high affinity for $A \beta$, where sequestered plasma $\mathrm{A} \beta$ will be routed to hepatic and splenic macrophages for destruction. This approach could potentially reduce or prevent brain amyloidosis. It should also be emphasized that NPs can be introduced into the body through different routes of administration. 
Notably, some efforts suggest that orally delivered NPs can improve bioavailability of certain drugs used in AD.

\section{Current Pharmacotherapy and Targeted NPS for the Treatment of AD}

Drug development of new agents for the symptomatic and disease-modifying treatment of $\mathrm{AD}$ has resulted in both promise and disappointment. Since, a large number of drugs with differing targets and mechanisms of action are available for the treatment of $\mathrm{AD}$. For instance, Phase III trials of nonsteroidal anti-inflammatory drugs (NSAIDs), phenserine, statins, tarenflurbil, tramiprosate, Ginkgo biloba and xaliproden have been completed. However, none of them has demonstrated a significant efficacy. Different randomized clinical trials in patients with MCI (Thal et al., 2005), at high risk for $\mathrm{AD}$ have found that NSAIDs were not effective treatments (Rogers et al., 1993; Scharf et al., 1999; Aisen et al., 2003). Phenserine is a selective choline esterase inhibitor (ChEI) that was found to inhibit the formation of $A \beta$ in animal studies (Thatte and Axonyx, 2006). It is well established that high cholesterol levels are associated with an increased risk of $\mathrm{AD}$ (Kivipelto and Solomon, 2006). Moreover, in animal models, hypercholesterolemia promotes $A \beta$ production and deposition (Sparks, 2008). Tarenflurbil is a $\gamma$-secretase inhibitor, results in the formation a multicenter, randomized, double-blind, placebo-controlled trial enrolling 1684 patients with mild $\mathrm{AD}$ have shown no significant effects after 18 months of treatment (Green et al., 2009). Tramiprosate is a modified amino acid taurine that functions as a glycosaminoglycan mimetic which can bind soluble $\mathrm{A} \beta$ peptides, and thus act as an antifibrillar agent that inhibits the formation of amyloid plaques (Greenberg et al., 2006). Due to the insufficiency in conventional delivery mechanisms intensive research done over the last few years has focused on the development of new strategies to more effectively deliver drug molecules across the BBB (Gabathuler, 2010). To overcome the limited access of drugs to the brain different strategies have been investigated that achieve $\mathrm{BBB}$ penetration including the osmotic BBB opening (Rapoport, 1996), biologically active agents (e.g., histamine, serotonin, substance $\mathrm{P}$, metalloproteinases, etc.) (Abbott and Revest, 1991), liposomes and NPs. Among the various nanocarriers used polymeric NPs are promising

\section{Physiochemical Properties of Brain Targeted Nanoparticles}

The size, surface and charge of the prepared NPs are important characteristics properties (Davis et al., 1997). NPs with a size greater than $100 \mathrm{~nm}$ are easily captured by Küpffer cells or other phagocytic cell populations which thus restrict their biodistribution. Hydrophilic nanoparticles with particle size less than $100 \mathrm{~nm}$ have been reported to avoid opsonization (Allemann et al., 1993) with a consequent prolonged circulation times to facilitate enhanced targeting of the drug to specific sites (Banerjee et al., 2002). Sonavane et al (2008) have evaluated the effect of increasing particle size on the biological distribution of NPs following i.v. administration (1 $\mathrm{g} / \mathrm{kg})$ of the NPs suspension prepared in sodium alginate solution $(0.5 \% \mathrm{w} / \mathrm{v})$ in mice. By varying the citrate ion concentration, gold NPs with 15 $\mathrm{nm}, 50 \mathrm{~nm}, 100 \mathrm{~nm}$ and $200 \mathrm{~nm}$ size were synthesized. Higher amount of NPs with 15 $\mathrm{nm}$ particle size was observed in all tissues including the blood, liver, lung, spleen, kidney, brain, heart and stomach. As compared to particles with size $15 \mathrm{~nm}$ and $50 \mathrm{~nm}$, which could pass the BBB easily, NPs with size $200 \mathrm{~nm}$ were present at the 
minimum level in different organs including the blood, brain, stomach and pancreas (Sonavane et al., 2008).

\section{Mechanism of Brain and Cellular Uptake of NPs}

Drug delivery to the brain for the treatment of NDs related to aging still remains a challenging task because traditional drug delivery systems have limited application due to the restrictions posed by the $\mathrm{BBB}$ with their low bioavailability. Over the last few decades, nanotechnology has been explored extensively as an area of potential research for the development of newer therapeutic modalities for the treatment of neurological disorders (table-2).

A concentration gradient due to an increased retention of NPs in the brain blood capillaries combined with an adsorption to capillary walls that would increase the transport of NPs across the endothelial cell layer for drug delivery; solubilization of endothelial cell membrane lipids leading to membrane fluidization; opening of tight junctions between endothelial cells thus leading to enhanced permeation of the drug in the nanoparticulate; endocytosis of the NP by endothelial cells followed by drug release within these cells of the brain; transcytosis of the NPs with attached drug across the endothelial cell layer; inhibition of the Pglycoprotein efflux system by coating the NPs with polysorbate 80 are some of the mechanisms proposed for the penetration of the NPs to the brain (Lockman et al., 2003).

Although, the exact mechanism(s) of transport are not known, the absence of toxicity at the BBB both in vitro and in situ suggests that NPs may be transported through the barrier by endocytosis or transcytosis or by passive diffusion in the absence of barrier opening. They may be designed to mimic low density lipoproteins and interact with their receptors, thereby triggering uptake by the endothelial cells of the brain (Faraji and Wipf, 2009).

\section{Different Approaches Used In The Treatment Of Alzheimer' Disease}

\section{(Imaging - based nanotechnologies for Alzheimer's diagnosis). Thioflavin $T$}

Thioflavin T (ThT) is a molecule capable of recognizing $\beta$ - sheet structures related to $A \beta$ aggregates both in vitro and in vivo. A recent attempt described the encapsulation of ThT into PS-b-PnBCA NPs, its release into the brain after intracerebral injection, and its interaction with $A \beta$ species, thereby showing clear visualization of amyloid aggregates (Siegemund et al., 2006).

\section{Quantum dots - AB Complex}

Fluorescent semiconductor nanocrystals (quantum dots, QDs) have evolved over the past decade as highly useful fluorescent probes for biological labeling and diagnostics. QD features include long-term photostability and physicochemical stability, nanoscale size, and size-dependent emission wavelength (Dubertret et al., 2002). Tokuraku et al designed poly(ethylene glycol) (PEG)-QDcrosslinked A $\beta$ peptide as a tool to monitor and to quantitatively describe the formation of fibrils and oligomers in solution and in a cellular system. This approach allowed the study of the $A \beta$ peptide aggregation kinetics but could also be used to follow the in vivo peptide aggregation (Tokuraku et al., 2009). The authors have considered the functionalization of these nanoassemblies with appropriate ligands such as transferring for BBB-crossing (Xu et al. 2008). 


\section{Gold NPs}

Gold NPs (Au NPs) also represent an interesting tool for studying $A \beta$ peptide aggregation kinetics. Choi et al described the synthesis of heterodimeric NPs consisting of a cobalt(II) magnetic core and a platinum shell directly fused onto Au NPs and stabilized by lipoic acid-polyethylene glycol coating (Choi et al., 2008).

The results with terminal carboxyl groups of the PEG chains enabled covalent binding with lysine residues of neutravidin at the surface of the NPs. The Co @ Pt-Au nano assemblies presented a high magnetization value [63 emu g-1 (Co) at $3 \mathrm{~T}$ ], making them appropriate for T2-weighted spin echo MRI measurements and also clearly showed that these NPs can be used in MRI to monitor key structural stages of $A \beta$ selfassembly. (Choi et al., 2008).

However, several important parameters should be considered before a viable application is foreseen. Indeed, the intrinsic in vitro, in vivo cytotoxicity of the employed materials used to prepare the NPs should be thoroughly evaluated before further investigations. The feasibility of these approaches will further depend on developments that do not depend on invasive procedures.

\section{Iron oxide NPS}

Magnetic iron oxide NPs have gained much interest because of their large surface area, magnetic properties, and limited toxicity. They have already been approved by the U.S. Food and Drug Administration (FDA) as MRI contrast agents in liver imaging (de Vries et al., 2005).

The synthesis of monocrystalline iron oxide NPs (MIONs) covalently tethered to the N terminus of $A \beta 1-40$ peptide through amide coupling and their development for the concomitant targeting and imaging of senile plaques has been reported (Wadghiri et al., 2003). These MRI agents, by means of longitudinal MRI, were able to recognize high-affinity $A \beta$ plaques in the brains of amyloid precursor protein (APP) and APP/PS1 transgenic mice when coinjected with mannitol (used to transiently open the BBB). Although this study is very encouraging and demonstrates the proof of concept, manipulation of the $\mathrm{BBB}$ remains questionable for human testing.

\section{Metal Chelators as Therapeutic Agents in Alzheimer's}

Iron $(940 \mu \mathrm{M})$, copper $(390 \mu \mathrm{M})$ and zinc $(1055 \mu \mathrm{M})$ have been reported to be elevated by several-folds in AD brain as compared to normal age-matched samples [copper (70 $\mu \mathrm{M})$, zinc $(350 \mu \mathrm{M})$ and iron $(340 \mu \mathrm{M})$ ] (Adlard and Bush, 2006; Lovell et al., 1998; Bush,2003). Zinc, copper, and iron have been shown in multiple studies to be markedly enriched in $A \beta$ plaques in transgenic mice (Castellani et al., 1999; Dong et al., 2003; Lee et al., 1999).

Metal chelators bind strongly to two or more metal ions and form a cyclic ring, which converts the metal ions into an inert form and depletes the total pool of bioavailable transition metals. The first such agent to enter clinical investigations for the treatment of $\mathrm{AD}$ is Desferrioxamine (DFO), an iron chelator with high binding affinities for zinc, copper and aluminum (Kebre, 1964). However, DFO is a large hydrophilic molecule, which is not orally bioavailable and does not normally penetrate the BBB. Cropper McLachlan et al (1991) have studied the beneficial effect seen with the $\mathrm{DFO}$ treatment in patients with $\mathrm{AD}$ was due to the drug's interaction or chelation of metals. 


\section{Beneficial Effects of Curcumin and Catechins on the Amyloid Cascade}

Polyphenols are among the new treatment options because numerous epidemiological studies have suggested an association between the consumption of polyphenolic phytochemical-rich foods or beverages and the prevention of certain neurological diseases, including AD (Singh et al., 2008). These compounds not only exhibit potent anti-oxidative and anti-inflammatory effects but can also target different pathways implicated in the pathogenesis of $\mathrm{AD}$ such as the attenuation of the production of the $\mathrm{A} \beta$, are given in the Table 1).
Green tea is rich in flavonoids (a class of polyphenol) with $30 \%$ of dry weight of a leaf (Graham,1992) and also it have shown beneficial effects in animal models of stroke/cerebral ischemia, $\mathrm{AD}$ and $\mathrm{PD}$. Neuroprotection in ischemia by EGCG may be mediated through reducing iNOS expression, peroxynitrite formation, preservation ofmitochondrial complex activity and integrity, or ferric iron chelation (Suzuki et al., 2004; Mandel et al., 2005; Sutherland et al., 2005). There are several in vitro studies that suggest green tea extract could protect neurons from the $A \beta$-induced damages (Bastianetto et al., 2006; Choi et al., 2001; Levites, 2003)

Table.1 Description of some Properties and Targets of Catechins and Curcumin for their Potential Beneficial Effects against AD

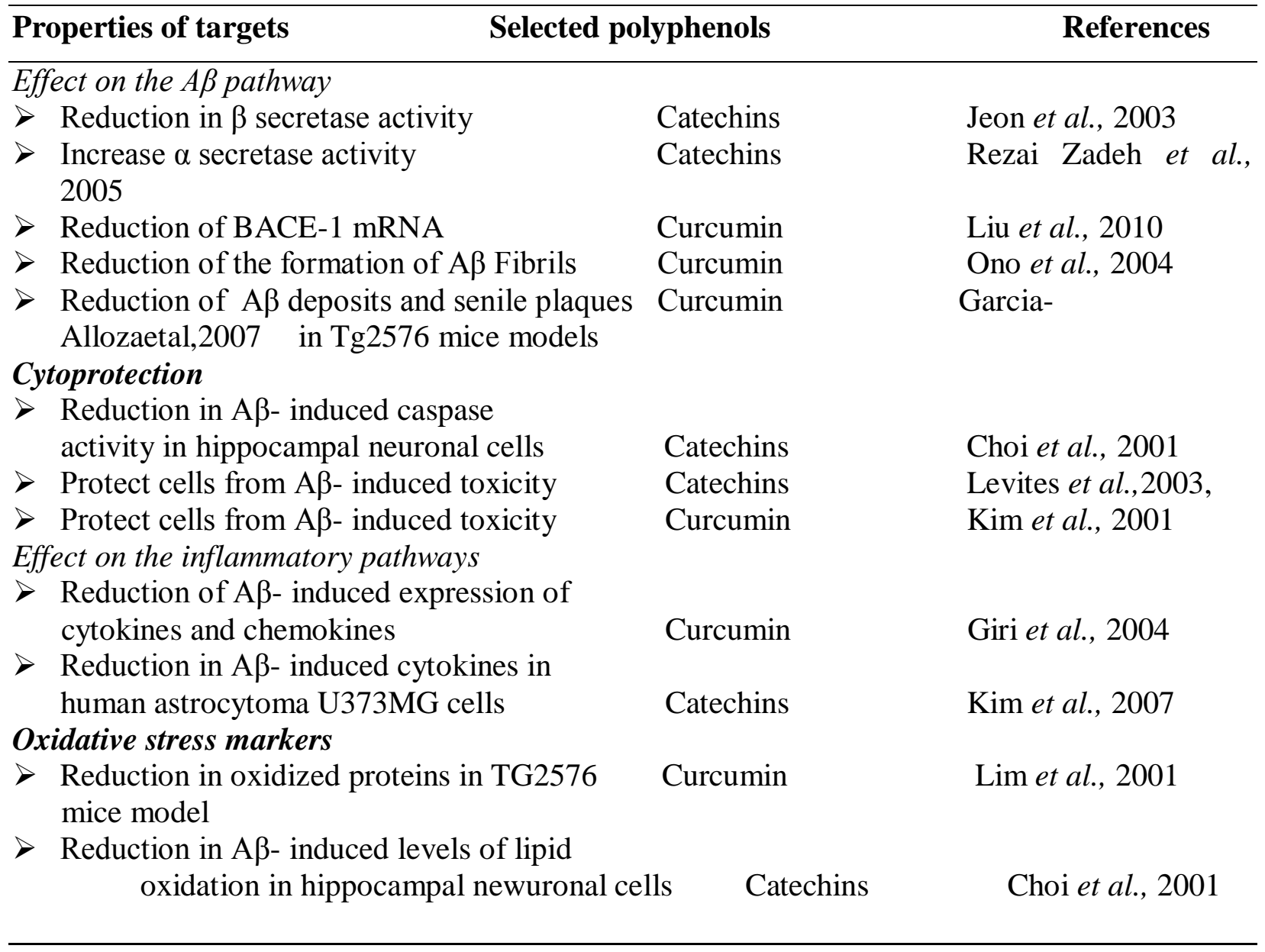


Int.J.Curr.Res.Aca.Rev.2016; 4(1): 132-145

Table.2 Drug Loaded -NPs Tested for the Treatment of AD

\begin{tabular}{|c|c|c|c|c|c|c|c|}
\hline S.No. & Drug & Types of nanoparticle & Model & $\begin{array}{l}\text { Route of } \\
\text { administration }\end{array}$ & Applications & $\begin{array}{l}\text { Particle } \\
\text { size }(\mathrm{nm})\end{array}$ & Reference \\
\hline 1. & $\begin{array}{l}\text { ChEIs } \\
\text {-Tacrine }\end{array}$ & $\begin{array}{l}\text { a) Polysorbate-80 } \\
\text { coated poly (n- } \\
\text { butylcyanoacrylate) } \\
\text { Chitosan } \\
\text { nanoparticles) } \\
\text { b) Chitosan } \\
\text { nanoparticles }\end{array}$ & Rats & I.v. injection & $\begin{array}{l}\text { Enhanced } \\
\text { concentration of the } \\
\text { drug in the brain } \\
\text { A new drug delivery } \\
\text { system for increasing } \\
\text { bioavailability of the } \\
\text { drug in the brain }\end{array}$ & $\begin{array}{l}35.5 \pm 4.64 \\
41 \pm 7\end{array}$ & $\begin{array}{l}\text { Wilson et } \\
\text { al., } 2008 \\
\text { Wilson et } \\
\text { al., } 2010\end{array}$ \\
\hline 2. & $\begin{array}{l}\text { Amyloid } \beta \\
\text { targeted } \\
\text { drugs } \\
\text {-Thioflavin } \\
\text { T and S }\end{array}$ & $\begin{array}{l}\text { Core-shell } \\
\text { nanoparticles } \\
\text { composed of a } \\
\text { polystyrene } \\
\text { core and a degradable } \\
\text { PBCA } \\
\text { [poly (butyl-2- } \\
\text { cyanoacrylate)] } \\
\text { shell }\end{array}$ & $\begin{array}{l}\mathrm{APP} / \mathrm{P} \\
\mathrm{S} 1 \\
\text { mice }\end{array}$ & $\begin{array}{l}\text { Intracerebrovent } \\
\text { ri-cular } \\
\text { injections }\end{array}$ & $\begin{array}{l}\text { Tools to trace and } \\
\text { clear } \\
A \beta \text { in the brain }\end{array}$ & - & $\begin{array}{l}\text { Siegemun } \\
\mathrm{d} \text { et al., } \\
2006\end{array}$ \\
\hline 3 & $\begin{array}{l}\text { Poly-phenol } \\
\text { EGCG }\end{array}$ & Nanolipidic particles & Rats & Oral & $\begin{array}{l}\text { Prevent brain beta } \\
\text { amyloid } \\
\text { plaque formation }\end{array}$ & $30-80$ & $\begin{array}{l}\text { Smith et } \\
\text { al., } 2010\end{array}$ \\
\hline 4. & $\begin{array}{l}\text { Amyloid- } \\
\text { beta }\end{array}$ & Chitosan nanoparticles & Mice & $\begin{array}{l}\text { Systemic } \\
\text { administration }\end{array}$ & $\begin{array}{l}\text { Nano-vaccine } \\
\text { delivery system could } \\
\text { be } \\
\text { used as a potential } \\
\text { carrier for Abeta }\end{array}$ & $\begin{array}{l}15.23 \pm 10.9 \\
7\end{array}$ & $\begin{array}{l}\text { Songjiang } \\
\text { and } \\
\text { Lixiang, } \\
2009\end{array}$ \\
\hline 5. & $\begin{array}{l}\text { Gold nano- } \\
\text { particles }\end{array}$ & - & - & - & $\begin{array}{l}\text { The prepared } \\
\text { nanoparticles } \\
\text { dissolve toxic protein } \\
\text { deposits of } A \beta 1-42 \\
\text { by the combined use } \\
\text { of weak microwave } \\
\text { fields and gold } \\
\text { nanoparticles } \\
\text { (AuNP) without any } \\
\text { bulk heating }\end{array}$ & - & $\begin{array}{l}\text { Bastus et } \\
\text { al., } 2007\end{array}$ \\
\hline 6. & $\begin{array}{l}\text { Proteins and } \\
\text { pepides-VIP }\end{array}$ & $\begin{array}{l}\text { Poly (ethylene } \text { glycol)- } \\
\text { poly (lactic acid) } \\
\text { nanoparticles modified } \\
\text { with wheat germ } \\
\text { agglutinin }\end{array}$ & Mice & $\begin{array}{l}\text { Intranasal } \\
\text { administration }\end{array}$ & $\begin{array}{l}\text { Improvement in brain } \\
\text { delivery of estradiol } \\
\text { using wheat germ } \\
\text { agglutinin } \\
\text { nanoparticles }\end{array}$ & $90-120$ & $\begin{array}{l}\text { Gao et al., } \\
2007\end{array}$ \\
\hline
\end{tabular}

Curcumin is a low molecular weight molecule with highly potential for antioxidant and anti-inflammatory activities.
Its yellow curry spice is part and parcel of Indian vegetables. When fed to aged $\mathrm{Tg} 2576$ mice, curcumin reduced $\mathrm{A} \beta$ levels and 
plaques (Yang et al., 2005). However, curcumin also blocked $\mathrm{A} \beta$ aggregation and fibril formation in vitro model (IC50 $=0.8$ $\mu \mathrm{M}$ ) (Yang et al., 2005) and this property could be implicated in the reduction of amyloid plaques burden observed in vivo after curcumin treatment of $\mathrm{Tg} 2576$ mice models. This antioxidant is also a good inhibitor of expression of inflammatory cytokines and cyclo-oxygenase- 2 likely by the inhibition of JNK/AP-1 and NF-kB mediated gene transcription (Aggarwal et al., 2003). However, it has restrictive pharmaceutical role because of its extremely low aqueous solubility, rapid systemic elimination, inadequate tissue absorption, poor absorption from the gut and degradation at alkaline $\mathrm{pH}$, which severely curtails its bioavailability (Anand et al., 2007; Wahlstrom and Blennow, 1978).

\section{Some Other Types of Nano Effective Drug Delivery System in the Treatment of Alzheimer's Disease}

\section{Polymeric Nanogels}

Nanogels are network of crosslinked polymers that often combine ionic and nonionic polymers chains that are prepared using an emulsification solvent evaporation approach (Bronich et al., 2006; Bontha et al., 2006). Nanogels swell in water and are able to incorporate molecules such as oligonucleotids, DNA, proteins and low molecular-mass drug. The drug-loading capacity is up to $40-60 \%$ have encapsulated within oligonucleotides within a cross linked nanogel for delivery across the BBB (Vinogradov et al., 2005). Nanogels are promising carriers for CNS drug delivery.

\section{Polymeric Nanoparticles}

Polymeric noparticles range from $10 \mathrm{~nm}$ to $1000 \mathrm{~nm}$ (Muller and Keck, 2004), nanoparticles possess high drug loading capacities if appropriately designed and are able to protect the incorporated drug-load against degradation and efficient targeting to the brain. Polymeric nanoparticles have been used for the CNS delivery of several drugs such as doxorubicin (Alyaudtin et al., 2001; Steiniger et al., 2004).

\section{Polymeric Nano-micelles}

Polymeric nano-micelles have core-shell structure with a hydrophilic core and a shell of hydrophilic polymer blocks. The core can incorporate up to $20-30 \%$ (w/w) of hydrophobic drugs,

Thus preventing premature drug release and degradation. Polymeric nano-micelles are versatile and have been shown to efficiently deliver DNA molecules in vitro and vivo, moreover, no successful study on their delivery to the CNS has been reported (Oishi et al., 2007; Nguyen et al., 2000).

\section{Conclusion}

Nanotechnology has a high potentially evolutionary impact on the basic understanding and pharmaco therapeutic approaches of neuroscience. It may contribute significantly towards the development of nano based effective drug system for the treatment of AD. Nanotechnologies have emerged that can manipulate $A \beta$ aggregation both in the brain and in the peripheral circulation, thus aiding experimental AD therapy. However, three important open questions remain to be answered before engaging in further research toward clinical investigations: (1) the efficiency of symptom alleviation by these nanoparticulate systems must be validated in representative $A D$ in case of vivo models, (2) FDA-approved macromolecules for nanoconstructs must be 
Int.J.Curr.Res.Aca.Rev.2016; 4(1): 132-145

employed, and (3) non invasive administrations of NPs must be considered for repeated and prolonged therapeutic purposes. These requirements are also relevant when considering the development of a strategy based on the development of NPs for physical interactions with $A \beta$ peptide. In this case the majority of the above-discussed studies were performed in buffer environments, a considerable simplification of physiological conditions. Recent achievements also described the synthesis of drug and the use of imaging agents and drugs based on nanoparticulate systems. Therefore, in order for nanotechnology applications directed towards $\mathrm{AD}$ to be fully exploited, it would be important for neurosurgeons, neurologists, and neuroscientists to participate and contribute to the scientific process along with pharmaceutical scientists and medical engineers. True to the highly interdisciplinary nature of this area of research, it is also important that nano technological advancements occur in conjunction with basic and clinical advancements in the field of neuroscience.

\section{References}

Augustinack, J.C., Schneider A., Mandelkow E.M., and Hyman, B.T. 2002. Specific tau phosphorylation sites correlate with severity of neuronal cytopathology in Alzheimer's disease, Acta Neuropathol, 103, 26-35.

Alyaudtin, R.N., Reichel, A., Lobenberg, R., Ramgel, P., Kreuter, J. and Begley, D.J. $2001 . \quad$ Interaction of polybutylcyanoacrylate nanoparticles with the blood-brain barrier in vivo and in vitro. J. Drug Target, 9, 209-221.

Aisen, P.S., Schafer, K.A., Grundman, M., Pfeiffer, E., Sano, M., Davis, K.L., Farlow, M.R., Jin, S., Thomas, R.G., Thal, and Cin, L.J. 2003. Effects of rofecoxib or naproxen vs placebo on Alzheimer disease progression: a randomized controlled trial, JAMA, 289 21, 2819-2826.

Abbott, N.J. and Revest, P.A. 1999. Control of brain endothelial permeability, Cerebrovasc. Brain Metab. Rev. 31 39-72.

Allemann, E., Leroux, J.C., Gurny, R., and Doelker, E. 1993.In vitro extendedrelease properties of drug-loaded polyDL-lactic acid nanoparticles produced by a salting-out procedure, Pharm. Res. 10 12, 1732-1737.

Adlard, P.A. and Bush, A.I. 2006. Metals and Alzheimer's disease, J. Alzheimers Dis, 10 2-3. 145-163.

Aggarwal, B.B., Kumar, A. and Bharti, A.C. 2003. Anticancer potential of curcumin: preclinical and clinical studies, Anticancer Res. 23 1A, 363-398.

Anand, P., Kunnumakkara, A.B., Newman, R.A. and Aggarwal, B.B. 2007. Bioavailability of curcumin: problems and promises, Mol. Pharm. 4 6, 807818.

Bastianetto, S., Yao, Z.X., Papadopoulos, V. and Quirion, R. 2006. Neuroprotective effects of green and black teas and their catechin gallate esters against beta-amyloidinduced toxicity, Eur. J. Neurosci, 23 1, 55-64.

Bush, A.I. 2003. The metallobiology of Alzheimer's disease, Trends Neurosci, 26 4, 207-214.

Banerjee, T., Mitra, S., Singh, A., Sharma, R. and Maitra, A. 2002. Preparation, characterization and biodistribution of ultrafine chitosan nanoparticles, Int. J. Pharm. 243 1-2 93-105.

Busciglio, J., Lorenzo, A., Yeh, J. and Yankner, B.A. 1995. $\beta$-Amyloid fibrils induce tau phosphorylation and loss of microtubule binding, Neuron, 14, 879888. 
Bronich, T.K., Bontha, S., Shlyakhtenko, L.S., Bromberg, L., Hatton, T.A. and Kabanov, A.V. 2006. Template-assisted synthesis of nanogels from pluronicmodified poly- acrylic acid. J. Drug Target, 14, 357-366.

Bastus, N.G., Kogan, M.J., Amigo, R., Grillo-Bosch, D., Araya, E., Turiel, A., Labarta, A., Giralt, E. and Puntes, V.F 2007. Gold nanoparticles for selective and remote heating of betaamyloid protein aggregates, Mater. Sci. Eng. C Biomim. Supramol. Syst, 27 5-8, 1236-1240.

Bontha, S., Kabanov, A.V. and Bronich, T.K. 2006. Polymer micelles with cross-linked ionic cores for delivery of anticancer drugs. J. Control. Release, 114, 163-174.

Castellani, R.J., Smith, M.A., Nunomura, A. and Harris, P.L. 1999. Perry G. Is increased redoxactive iron in Alzheimer disease a failure of the copper-binding protein ceruloplasmin? Free Radic. Biol. Med. 26 11-12, 1508-1512.

Crapper McLachlan, D.R., Dalton, A.J., Kruck, T.P., Bell, M.Y., Smith, W.L., Kalow, W. and Andrews, D.F. 1991. Intramuscular desferrioxamine in patients with Alzheimer's disease, Lancet 337 8753, 1304-1308.

Choi, Y.T., Jung, C.H., Lee, S.R., Bae, J.H., Baek, W.K., Suh, M.H., Park, J., Park, C.W. and Suh, S.I. 2001. The green tea polyphenol --epigallocatechin gallate attenuates betaamyloid-induced neurotoxicity in cultured hippocampal neurons, Life Sci, 70 5, 603-614.

Choi, J.S., Choi, H.J., Jung, D.C., Lee, J.H. and Cheon, J. 2008. Nanoparticle assisted magnetic resonance imaging of the early reversible stages of amyloid $\beta$ self-assembly. Chem Commun, 21, 97103.

de Vries, I.J., Lesterhuis, W.J., Barentsz, J.O.,Verdijk, P., van Krieken, J.H. and
Boerman, O.C. 2005. Magnetic resonance tracking of dendritic cells in melanoma patients for monitoring of cellular therapy. Nat Biotechnol, 23:1407-13.

Davis, S.S. 1997. Biomedical applications of nanotechnology- implications for drug targeting and gene therapy, Trends Biotechnol, 15 6, 217-224.

Dubertret, B., Skourides, P., Norris, D.J., Noireaux, V., Brivanlou, A.H. and Libchaber, A. 2002. In vivo imaging of quantum dots encapsulated in phospholipid micelles. Science, 298, 1759-62.

Dong, J., Atwood, C.S., Anderson, V.E., Siedlak, S.L., Smith, M.A., Perry, G. and Carey, P.R. 2003. Metal binding and oxidation of amyloid-beta within isolated senile plaque cores: Raman microscopic evidence, Biochemistry, 42, 10, 2768-2773.

Ferri, C.P., Prince, M., Brayne, C., Brodaty, H., Fratiglioni, L., Ganguli, M., Hall, K., Hasegawa, K., Hendrie, H., Huang, Y., Jorm, A., Mathers, C., Menezes, P.R., Rimmer, E. and Scazufca, M. 2005. Global prevalence of dementia: a Delphi consensus study, Lancet, 366, 9503, 2112-2117.

Faraji, A.H. and Wipf, P. 2009. Nanoparticles in cellular drug delivery, Bioorg. Med. Chem, 17 8, 2950-2962.

Ferreira, A., Lu, Q., Orecchio, L. and Kosik, K.S. 1997. Selective phosphorylation of adult tau isoforms in mature hippocampal neurons exposed to fibrillar A $\beta$, Mol. Cell, Neurosci, 9, 220-234.

Gao, X., Wu, B., Zhang, Q., Chen, J., Zhu, J., Zhang, W., Rong, Z., Chen, H. and Jiang, X. 2007. Brain delivery of vasoactive intestinal peptide enhanced with the nanoparticles conjugated with wheat germ agglutinin following 
intranasal administration, J. Control. Release, 121, 3 156-167.

Garcia-Alloza, M., Borrelli, L.A., Rozkalne, A., Hyman, B.T. and Bacskai, B.J. 2007. Curcumin labels amyloid pathology in vivo, disrupts existing plaques, and partially restores distorted neurites in an Alzheimer mouse model, J. Neurochem, 102 4, 1095-1104.

Giri, R.K., Rajagopal, V. and Kalra, V.K. 2004. Curcumin, the active constituent of turmeric, inhibits amyloid peptideinduced cytochemokine gene expression and CCR5- mediated chemotaxis of THP-1 monocytes by modulating early growth response-1 transcription factor, J. Neurochem, 91 5, 1199-1210.

Green, R.C., Schneider, L.S., Amato, D.A., Beelen, A.P., Wilcock, G., Swabb, E.A. and Zavitz K.H. 2009. Effect of tarenflurbil on cognitive decline and activities of daily living in patients with milAlzheimer disease: a randomized controlled trial, JAMA, 302 23. 25572564.

Greenberg, S.M., Rosand, J., Schneider, A.T., Creed Pettigrew, L., Gandy, S.E., Rovner, B., Fitzsimmons, B.F, Smith, E.E., Edip Gurol, M., Schwab, K., Laurin, J. and Garceau, D. 2006. A phase 2 study of tramiprosate for cerebral amyloid angiopathy, Alzheimer Dis. Assoc. Disord, 20 4, 269-274.

Gabathuler, R. 2010. Approaches to transport therapeutic drugs across the blood-brainbarrier to treat brain diseases, Neurobiol. Dis, 37 1, 48-57.

Graham, H.N. 1992. Green tea composition, consumption, and polyphenol chemistry, Prev. Med, 21 3, 334-350.

Hansen, R.A., Gartlehner, G., Webb, A.P., Morgan, L.C., Moore, C.G. and Jonas, D.E. 2008. Efficacy and safety of donepezil, galantamine, and rivastigmine for the treatment of Alzheimer's disease: a systematic review and meta-analysis, Clin. Interv. Aging, 3, 211-225.

Hong, S.H., Kim, H.M. and Um, J.Y. 2007. Epigallocatechin-3-gallate suppresses NF-kappaB activation and phosphorylation of p38 MAPK and JNK in human astrocytoma U373MG cells, J. Nutr. Biochem, 18 9, 587-596..

Jeon, S.Y., Bae, K.H., Seong, Y.H. and Song, K.S. 2003. Green tea catechins as a BACE1 betasecretase inhibitor, Bioorg. Med. Chem. Lett, 13 22, 39053908.

Kivipelto, M. and Solomon, A. 2006. Cholesterol as a risk factor for Alzheimer's disease epidemiological evidence, Acta Neurol. Scand. Suppl, 185, 50-57.

Kim, S.J., Jeong, H.J., Lee, K.M., Myung, N.Y., An, N.H., Yang, W.M., Park, S.K., Lee, H.J., Kim, D.S, Park, S.Y. and Kim, J.K. 2001. Curcuminoids from Curcuma longa L. Zingiberaceaethat protect $\mathrm{PC} 12$ rat pheochromocytoma and normal human umbilical vein endothelial cells from betaA1-42 insult, Neurosci. Lett, 303 $1,57-61$.

Lockman, P.R., Oyewumi, M.O., Koziara, J.M., Roder, K.E., Mumper, R.J. and Allen, D.D. 2003 Brain uptake of thiamine-coated nanoparticles, J. Control. Release , 93, 271-282.

Lovell, M.A., Robertson, J.D., Teesdale, W.J., Campbell, J.L. and Markesbery, W.R. 1998. Copper, iron and zinc in Alzheimer's disease senile plaques, J. Neurol. Sci, 158 1 47-52.

Levites, Y., Amit, T., Mandel S. and Youdim, M.B. 2003. Neuroprotection and neurorescue against Abeta toxicity and PKC-dependent release of nonamyloidogenic soluble precursor 
protein by green tea polyphenol -epigallocatechin-3-gallate, FASEB J. 17 8, 952-954.

Lee, J.Y., Mook-Jung, I. and Koh, J.Y. 1999. Histochemically reactive zinc in plaques of the Swedish mutant betaamyloid precursor protein transgenic mice, J. Neurosci, 19 11, RC10.

Murphy, M.P. and LeVine, H. 2010. Alzheimer's disease and the amyloidbeta peptide, J. Alzheimers Dis, 19, 311-323.

Liu, H., Li, Z., Qiu, D., Gu, Q., Lei, Q. and Mao, L. 2010. The inhibitory effects of different curcuminoids on beta-amyloid protein, beta-amyloid precursor protein and beta-site amyloid precursor protein cleaving enzyme 1 in swAPP HEK293 cells, Neurosci. Lett, 485 2, 83-88.

Lim, G.P., Chu, T., Yang, F., Beech, W., Frautschy, S.A. and Cole, G.M. 2001. The curry spice curcumin reduces oxidative damage and amyloid pathology in an Alzheimer transgenic mouse, J. Neurosci, 21 21, 8370-8377.

Mandel, S.A., Avramovich-Tirosh, Y., Reznichenko, L., Zheng, H.L, Weinreb, O., Amit, T., Youdim, M.B.H. 2005. Multifunctional activities of green tea catechins in neuroprotection modulation of cell survival genes, irondependent oxidative stress and PKC signaling pathway, Neurosignals, $141-$ 2, 46-60.

Molino, I., Colucci, L., Fasanaro, A.M., Traini, E. and Amenta, F. 2013. Efficacy of memantine, donepezil, or their association in moderate-severe Alzheimer's disease: a review of clinical trials, ScientificWorldJournal. http://dx.doi.org/10.1155/2013/ 925702.

Muller, R.H. and Keck, C.M. 2004. Drug delivery to the brain-realization by novel drug carriers. J. Nanosci. Nanotechnol, 4, 471-483.
Nguyen, H.K., Lemieux, P. and Vinogradov, S.V. 2000. Evaluation of polyetherpolyethyleneimine graft copolymers as gene transfer agents. Gene Ther, 7, 126-131

Oishi, M., Hayashi, H., Iijima, M. and Nagasaki, Y. 2007. Endosomal release and intracellular delivery of anticancer drugs using $\mathrm{pH}$-sensitive pegylated nanogels. J. Mater. Chem, 17, 37203725 .

Ono, K., Hasegawa, K., Naiki, H. and Yamada, M. 2004. Anti-amyloidogenic activity of tannic acid and its activity to destabilize Alzheimer's beta-amyloid fibrils in vitro, Biochim. Biophys. Acta, 1690 3, 193-202.

Parent, M.J., Bedard, M.A., Aliaga, A, Minuzzi, L., Mechawar, N., Soucy, J.P., Schirrmacher, E., Kostikov, A., Gauthier, S.G. and Rosa-Neto, P. 2013. Cholinergic depletion in Alzheimer's disease shown by $\left[\begin{array}{ll}18 & F\end{array}\right]$ FEOBV autoradiography, Int. J. Mol. Imaging,

Rapoport, S.I. 1996. Modulation of bloodbrain barrier permeability, J. Drug Target, 6, 417-425.

Rezai-Zadeh, K., Shytle, D., Sun, N., Mori, T., Hou, H., Jeanniton, D., Ehrhart, J., Townsend, K., Zeng, J., Morgan, D., Hardy, J., Town, T. and Tan, J. 2005. Green tea epigallocatechin- 3-gallate EGCG modulates amyloid precursor protein cleavage and reduces cerebral amyloidosis in Alzheimer transgenic mice, J. Neurosci, 25 38, 8807-8814.

Rogers, J., Kirby, L.C., Hempelman, S.R., Berry, D.L., McGeer, P.L., Kaszniak, A.W., Zalinski, J., Cofield, M., Mansukhani, L., Willson, P. and Kogan, F. 1993. Clinical trial of indomethacin in Alzheimer's disease, Neurology, 43 8, 1609-1611.

Scharf, S.,Mander, A., Ugoni, A., Vajda, F. and Christophidis, N. 1999. A doubleblind, placebocontrolled trial of 
diclofenac/misoprostol in Alzheimer's disease, Neurology, 53, 1 197-201.

Singh, M., Arseneault, M., Sanderson, T., Murthy, V. and Ramassamy, C. 2008. Challenges for research on polyphenols from foods in Alzheimer's disease: bioavailability, metabolism, and cellular and molecular mechanisms, J. Agric. Food Chem, 56 13, 4855-4873.

Sutherland, B.A., Shaw, O.M., Clarkson, A.N., Jackson, D.N., Sammut, I.A. and Appleton, I. 2005. Neuroprotective effects of --epigallocatechin gallate following hypoxiaischemia- nduced brain damage: novel mechanisms of action, FASEB J, 19 2, 258-260.

Suzuki, M., Tabuchi, M., Ikesda, M., Umegaki, K. and Tomita, T. 2004. Protective effects of green tea catechins on cerebral ischemic damage, Med. Sci. Monit, 10 6, BR166-BR174.

Sparks, D.L. 2008. The early and ongoing experience with the cholesterol-fed rabbit as a model of Alzheimer's disease: the old, the new and the pilot, J. Alzheimers Dis, 15 4, 641-656.

Sinha, S. and Lieberburg, I. 1999. Cellular mechanisms of beta-amyloid production and secretion, Proc. Natl. Acad. Sci. U. S. A, 96, 11049-11053.

Siegemund, T., Paulke, B.R., Schmiedel, H., Bordag, N., Hoffmann, A., Harkany, T., Tanila, H., Kacza, J. and Hartig, W. 2006. Thioflavins released from nanoparticles target fibrillar amyloid beta in the hippocampus of APP/PS1 transgenic mice, Int. J. Dev. Neurosci, 24 2-3 195-201.

Smith, A., Giunta, B., Bickford, P.C., Fountain, M., Tan, J. and Shytle, R.D. 2010. Nanolipidic particles improve the bioavailability and alpha-secretase inducing ability of epigallocatechin-3gallate EGCG for the treatment of Alzheimer's disease, Int. J. Pharm, 389 1-2, 207-212.
Songjiang, Z. and Lixiang, W. 2009. Amyloid-beta associated with chitosan nano-carrier has favorable immunogenicity and permeates the BBB, AAPS PharmSciTech, 103 900905.

Sun, L., Liu, S.Y., Zhou, X.W., Wang, X.C, Liu, R., Wang, Q. and Wang J.Z. 2003. Inhibition of protein phosphatase 2Aand protein phosphatase 1 -induced tau hyperphosphorylation and impairment of spatial memory retention in rats, Neuroscience, 118, 1175-1182.

Steiniger, S.C., Kreuter, J. and Khalansky, A.S. 2004. Chemotherapy of glioblastoma in rats using doxorubicinloaded nanoparticles. Int. J. Cancer, 109, 759-767.

Silva, G.A. 2010. Nanotechnology applications and approaches for neuroregeneration and drug delivery to the central nervous system. Ann N Y Acad Sci, 1199, 221-30.

Thal, L.J., Ferris, S.H., Kirby, L., Block, G.A, Lines, C.R., Yuen, E., Assaid, C., Nessly, M.L, Norman, B.A., Baranak, C.C. and Reines, S.A. 2005. A randomized, double-blind, study of rofecoxib in patients with mild cognitive impairment, Neuropsychopharmacology, $30 \quad 6$, 1204-1215.

Teipel, S.J., Meindl, T., Grinberg, L., Grothe, M., Cantero, J.L., Reiser, M.F., Moller, H.J., Heinsen, H. and Hampel, H. 2011. The cholinergic system in mild cognitive impairment and Alzheimer's disease: an in vivo MRI and DTI study, Hum. Brain Mapp, 32, 1349-1362.

Tokuraku, K., Marquardt, M. and Ikezu, T. 2009. Real-time imaging and quantification of amyloid- $\beta$ peptide aggregates by novel quantum-dot nanoprobes. PLoS One, 4:e8492. 
Thatte, U. and Axonyx, N. 2006. Phenserine, Curr. Opin. Investig. Drugs, 6 7, 729-739

Sonavane, G., Tomoda, K. and Makino, K. 2008. Biodistribution of colloidal gold nanoparticles after intravenous administration: effect of particle size, Colloids Surf. B Biointerfaces, 662. 274-280.

Vinogradov, S.V., Zeman, A.D., Batrakova, E.V., and Kabanov, A.V. 2005. Polyplex nanogel formulations for drug delivery of cytotoxic nucleoside analogs. J. Control. Release, 107, 143157.

Wadghiri, Y.Z., Sigurdsson, E.M., Sadowski, M., Elliott, J.I., Li, Y. and Scholtzova, H. 2003. Detection of Alzheimer's amyloid in transgenic mice using magnetic resonance microimaging. Magn Reson Med, 50:293-302.

Wilson, B., Samanta, M.K., Santhi, K., Kumar, K.P.S., Ramasamy, M. and Suresh, B. 2010.Chitosan nanoparticles as a new delivery system for the antiAlzheimer drug tacrine, Nanomed. Nanotechnol. Biol. Med, 6 1, 144-152. Wilson, B., Samanta, M.K., Santhi, K., Kumar, K.P.S., Paramakrishnan, N. and Suresh, B. 2008. Targeted delivery of tacrine into the brain with polysorbate 80-coated polyn-butylcyanoacrylate nanoparticles, Eur. J. Pharm. Biopharm, $701,75-84$.

Wahlstrom, B. and Blennow, G. 1978. A study on the fate of curcumin in the rat, Acta Pharmacol. Toxicol. Copenh., 43 2, 86-92.

Xu, G., Yong, K.T., Roy, I., Mahajan, S.D., Ding, H. and Schwartz, S.A. 2008. Bioconjugated quantum rods as targeted probes for efficient transmigration across an in vitro bloodbrain barrier. Bioconjug Chem, 19:1179-85.

Yang, F., Lim, G.P., Begum, A.N., Ubeda, O.J., Simmons, M.R., Ambegaokar, S.S, Chen, P.P., Kayed, R., Glabe, C.G., Frautschy, S.A. and Cole, G.M. 2005. Curcumin inhibits formation of amyloid beta oligomers and fibrils, binds plaques, and reduces amyloid in vivo, J. Biol. Chem, 28072005 58925901.

Zheng, W.H., Bastianetto, S., Mennicken, F., Ma ,W. and Kar, S. 2002. Amyloid $\beta$ peptide induces tau phosphorylation and loss of cholinergic neurons in rat primary septal cultures, Neuroscience, 115, 201-211.

\section{How to cite this article:}

Rakesh Kumar Singh. 2016. Approaches on Nano-based drug delivery for Alzheimer's Disease: Methods for Diagnosis, Pharmacology and Safety matter. Int.J.Curr.Res.Aca.Rev. 4(1): 132-145. doi: http://dx.doi.org/10.20546/ijcrar.2016.401.012 